\title{
PENGARUH ALTMAN Z-SCORE" DAN SPRINGATE S-SCORE SEBAGAI ALAT PREDIKSI POTENSI KEBANGKRUTAN TERHADAP HARGA SAHAM (pada perusahaan batubara yang listing di bursa efek indonesia periode 2016-2018)
}

\author{
Dirvi Surya Abbas ${ }^{1}$ \\ Fakultas Ekonomi dan Bisnis, Universitas Muhammadiyah Tangerang \\ abbas.dirvi@gmail.com \\ Kusdianto $^{2}$ \\ Fakultas Ekonomi dan Bisnis, Universitas Muhammadiyah Tangerang \\ rdkusdi17@gmail.com \\ Lailatul Inayah ${ }^{3}$ \\ Fakultas Ekonomi dan Bisnis, Universitas Muhammadiyah Tangerang \\ Lailatulinayah12@gmail.com
}

\begin{abstract}
This study aims to determine whether the information Altman Z-Score "and Springate SScore are used by investors to make investment decisions that are reflected in the Share Price. Altman Z-Score "and Springate S-Score measured by financial ratios that include working capital to total assets, retained earnings to total assets, earnings before interest and taxes to total assets, book value of equity to book value of total debt, net profit before taxes to current liabilities, and sales to total assets. This study uses a sample of coal sector companies during 2015-2018 using a purposive sampling method. The data used is obtained from annual reports that are listed on the Indonesia Stock Exchange. There are 12 companies for 3 years that meet the criteria. The analytical method used is multiple linear regression analysis with the help of SPSS version 16.0. The results of this study indicate that partially Altman Z-Score", it can be concluded that the Altman Z-Score variable "in this study has an influence on stock prices. Altman Z-Score" has a positive direction regression coefficient of 20.871 (20.87\%) with a negative direction constant of -6.900 , while a Springate S-Score it can be concluded that the Springate S-Score variable in this study does not have an influence on stock prices.

Keywords: Altman Z-Score”, Springate S-Score, Stock Price, Prediction Potential bankruptcy
\end{abstract}

\begin{abstract}
ABSTRAK
Penelitian ini bertujuan untuk mengetahui apakah informasi Altman Z-Score" dan Springate S-Score digunakan oleh investor untuk mengambil keputusan investasi yang tercermin dari Harga Saham. Altman Z-Score" dan Springate S-Score yang diukur dengan rasio keuangan yang mencakup yaitu working capital to total asset, retained earning to total asset, earning before interest and taxes to total asset, book value of equity to book value of total debt, net profit before taxes to current liabilities, dan sales to total assets. Penelitian ini menggunakan sampel perusahaan sektor Batubara selama tahun 2015-2018 dengan menggunakan metode purposive sampling. Data yang digunakan diperoleh dari laporan tahunan yang terdaftar di Bursa Efek Indonesia. Ada 12 perusahaan selama 3 tahun yang memenuhi kriteria. Metode analisis yang digunakan adalah analisis regresi linier berganda dengan bantuan SPSS versi 16.0. Hasil penelitian ini menunjukan bahwa variabel Altman Z-Score" dalam penelitian ini memiliki pengaruh terhadap Harga Saham. Altman Z-Score" mempunyai koefisien regresi kearah positif sebesar 20,871 (20,87\%) dengan Konstanta kearah negatif sebesar -6.900, sementara variabel Springate S-Score dalam penelitian ini tidak memiliki pengaruh terhadap Harga Saham.
\end{abstract}

Kata Kunci : Altman Z-Score”, Springate S-Score, Harga Saham, Prediksi potensi

kebangkrutan 


\section{A. PENDAHULUAN}

Di tengah kondisi pasar luar negeri yang serba tak pasti dan membuat harga batu bara turun sebanyak 20\% sejak awal tahun 2019, namun komoditas ini masih menjadi andalan di dalam negeri. Sepanjang semester I/2019, produksi batu bara nasional 2019 masih belum signifikan dibandingkan dengan realisasi sepanjang tahun lalu yang mencapai 557 juta ton. Berdasarkan data dari Direktorat Jenderal Mineral dan Batubara Kementerian ESDM, hingga 17 Juni 2019 produksi batu bara nasional batu mencapai 167,63 juta ton atau $34,23 \%$ dari target yang ditetapkan sebanyak 489,73 juta ton. Adapun pasokan untuk kebutuhan dalam negeri (domestic market obligation/DMO) tercatat sebanyak 35,22 juta ton. Namun, presentasinya tergolong tinggi dengan menyentuh angka atau 27,51 persen dari target sebanyak 128,04 juta ton. Meskipun produksi pada semester I/2019 masih tergolong rendah, secara historis. Badan Pusat Statistik (BPS) mencatat nilai ekspor batu bara pada Januari-Juni 2019 sebesar US\$ 11,22 miliar, turun $4,98 \%$ dibandingkan periode yang sama pada tahun lalu US\$ 11,81 juta. Turunnya harga jual akibat pasokan yang berlebih disebut menjadi faktor pemicu turunnya ekspor periode tersebut. BPS bahkan mencatat, pada Juni 2019 ekspor batu bara anjlok sebesar $14,42 \%$ menjadi US\$ 1,7 miliar dari periode yang sama tahun sebelumya US\$ 1,99 miliar. (katadata; 2019)

\section{HBA 2019}

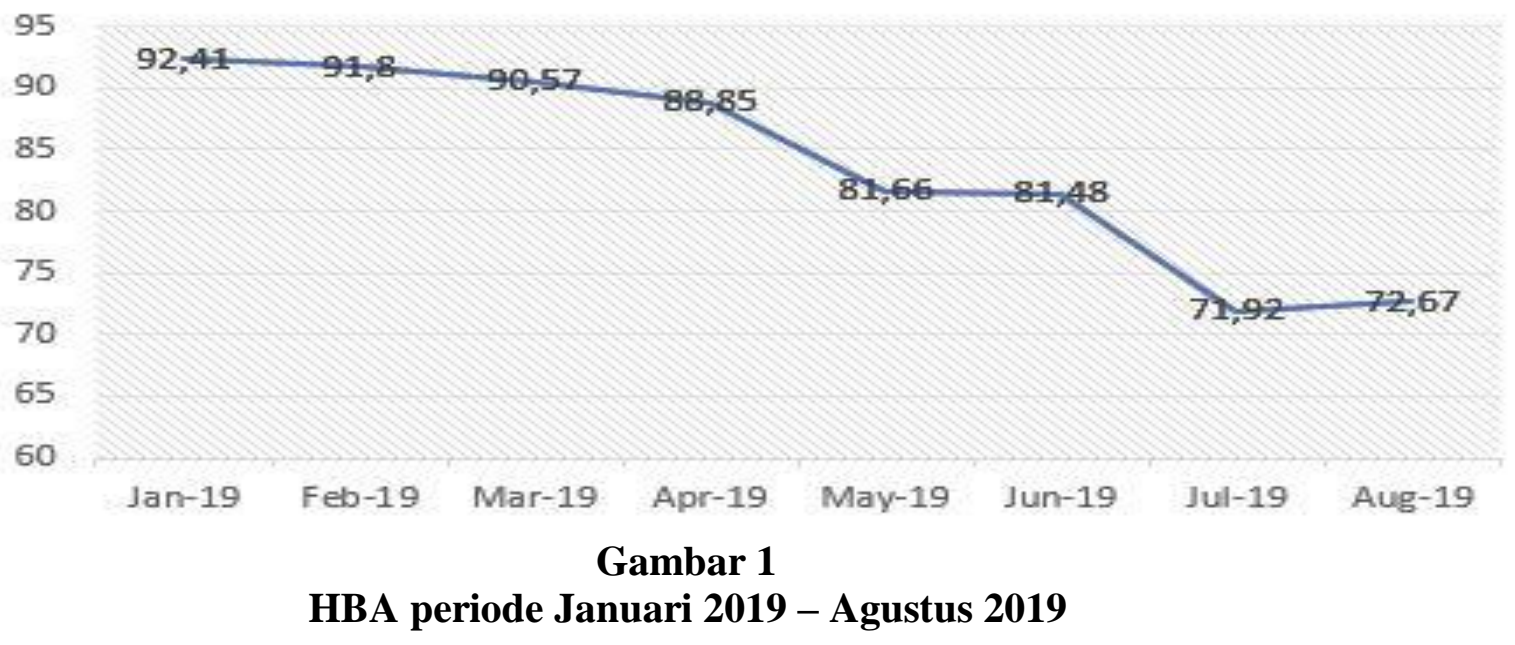

HBA April 2019 turun 1,89\% dibandingkan dengan HBA Maret 2019 yang tercatat US\$ 90,57 per ton. Terakhir kali HBA terlihat berada di atas level US\$ 100 per ton pada Oktober 2018 yakni sebesar US\$ 100,89 per ton. Menurut Direktur Eksekutif Asosiasi Pertambangan Batu Bara Indonesia (APBI) mengatakan bahwa penurunan nilai ekspor ditahun
2019 ini disebabkan oleh anjloknya harga batu bara, baik di global maupun dalam negeri. Penurunan itu juga dipicu oleh berlebihnya pasokan di pasar global, terutama sejak Rusia dan Kolombia memasok batu baranya ke Asia. Selama dua tahun terakhir, posisi HBA September tercatat paling rendah. Harga batubara mulai melemah sejak awal tahun 2019, 
meningkat tipis pada Agustus, dan terjun bebas kembali pada September.

melihat harga batubara yang semakin turun.

Pengusaha batubara makin lesuh

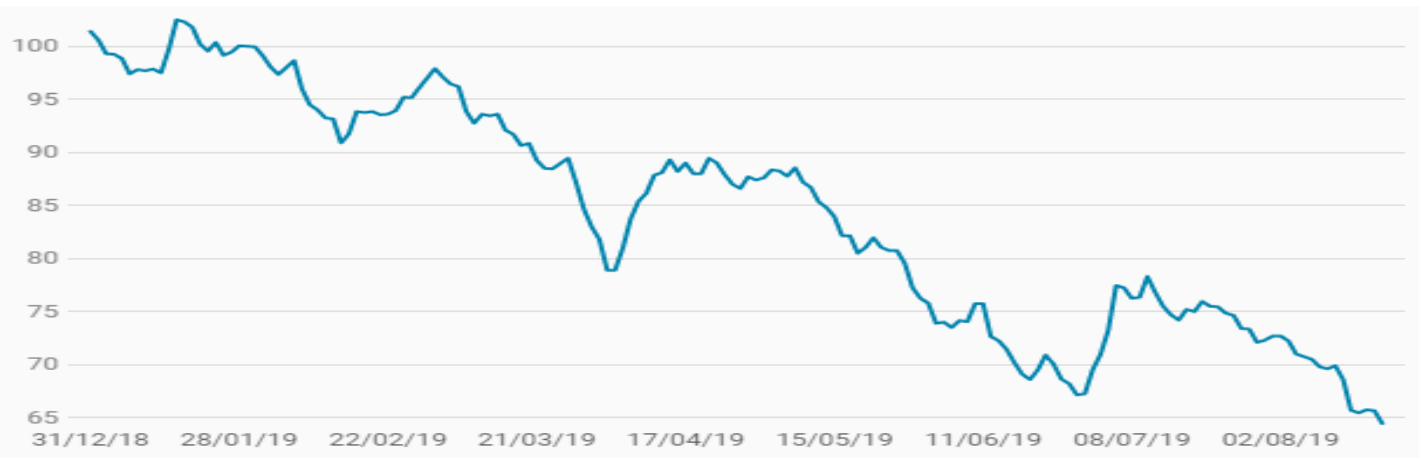

Gambar 2

Harga Batu Bara Newcastle Berjangka (US\$/Metrik Ton)

Melemahnya harga jual batubara di dunia dimulai pada tahun 2013 dan terus menurun hingga 2018 seakan memberikan pengaruh buruk terhadap industri batubara di Indonesia. Beberapa hal yang diduga sebagai penyebab perlambatan pertumbuhan batubara di Indonesia adalah seperti kebijakan dari Pergerakan harga batubara dipengaruhi oleh tingkat permintaan China dan India. Saat ini China tengah membatasi impor batubara karena sedang menggenjot produksi di dalam negeri. Sama halnya yang dilakukan oleh Pemerintah India melakukan pembatasan impor batubara. (duniatambang; 2019). Kedua negara tersebut merupakan mitra dagang penting bagi Indonesia karena lebih dari $50 \%$ produksi batubara diimpor kedua negara tersebut. Faktor lain yang mempengaruhi harga batubara adalah perang dagang China dan Amerika Serikat yang belum reda, menurunnya permintaan batubara dari benua Eropa dan kondisi pasar yang masih oversupply sehingga harga batubara masih dapat berubah.

Harga jual batubara mengalami kemerosotan dikarenakan kelebihan suplai dan kapasitas batubara di pasar. Kelebihan suplai terjadi di pasar China, karena menurunnya permintaan batubara di China sebesar 31,11 juta ton pada tahun 2014. Harga Batubara Acuan (HBA) yang digunakan pemerintah Indonesia mengalami penurunan menjadi USD $64,65 /$ ton pada akhir bulan desember. Penurunan yang terjadi adalah 1,6\% dibandingkan dengan HBA November 2014 yaitu USD 65,7/ton. Penurunan juga terjadi apabila dibandingkan dengan tahun sebelumnya yaitu pada tahun 2013 sebesar USD 15,66 atau turun $19 \%$ pada bulan yang sama.

Dikutip dari (Cnbc Indonesia; 2019) Memasuki sesi II perdagangan di Bursa Efek Indonesia (BEI) harga saham emiten batu bara masih banyak yang mencatatkan koreksi. Data pasar menunjukkan dari 25 emiten batu bara yang masih aktif diperdagangkan, 10 emiten berada di zona merah, 6 emiten anteng di zona hijau, dan 6 emiten stagnan. Sementara itu 3 emiten masih dihentikan sementara perdagangannya (suspensi), yaitu PT Bara Jaya Internasional tbk (ATPK), PT Borneo 
Lumbung Energy \& Metal Tbk (BORN), dan PT Golden Energy Mines Tbk (GEMS). Berdasar tabel di bawah ini, terlihat bahwa emiten batu bara dengan kapitalisasi pasar (market capitalization/market cap) terbesar $\begin{array}{lll}\text { adalah } & \text { PT }\end{array}$

Tabel 1

\begin{tabular}{|c|c|c|c|}
\hline \multicolumn{4}{|c|}{ Kinerja Perdagangan Emiten Batu Bara Yang Terdaftar Dalam BEI } \\
\hline Perusahaan & $\begin{array}{l}\text { Kapitalisasi Pasar } \\
\text { (Triliun Rp) }\end{array}$ & $\begin{array}{c}\text { Rata-Rata } \\
\text { Volume } \\
\text { Perdagangan } \\
\text { (Juta Transaksi) }\end{array}$ & $\begin{array}{l}\text { Rata-Rata Turnover } \\
\text { (Miliar Rp) }\end{array}$ \\
\hline PT Bayan Resources Tbk/BYAN & 57.00 & 0.02 & 0.41 \\
\hline PT Adaro Energy Tbk/ADRO & 44.14 & 61.52 & 82.88 \\
\hline PT Bukit Asam Tbk/PTBA & 34.33 & 23.88 & 84.04 \\
\hline PT Indo Tambangraya Megah Tbk/ITMG & 19.55 & 1.81 & 37.55 \\
\hline PT Golden Energy Mines Tbk/GEMS & 15.00 & 0.00 & 0.00 \\
\hline PT Dian Swastatika Sentosa Tbk/DSSA & 11.17 & 0.00 & 0.01 \\
\hline PT Indika Energy Tbk/INDY & 9.09 & 20.11 & 37.57 \\
\hline PT Bumi Resources TbK/BUMI & 7.73 & 334.68 & 47.07 \\
\hline PT Alfa Energi Investama Tbk/FIRE & 5.90 & 9.50 & 60.97 \\
\hline PT Baramulti Suksessarana Tbk/BSSR & 4.42 & 0.01 & 0.03 \\
\hline PT Delta Dunia Makmur Tbk/DOID & 4.39 & 28.93 & 16.93 \\
\hline PT Harum EnergY TbK/HRUM & 3.80 & 4.67 & 7.18 \\
\hline РT Toba Bara Sejahtra Tbk/TOBA & 3.40 & 0.04 & 16.83 \\
\hline PT Samindo Resources Tbk/MYOH & 2.92 & 0.54 & 0.68 \\
\hline PT Mitrabara Adiperdana TbK/MBAP & 2.76 & 0.08 & 0.21 \\
\hline PT Borneo Olah Sarana Sukses Tbk/BOSS & 2.63 & 1.78 & 3.36 \\
\hline PT Atlas Resources Tbk/ARII & 2.40 & 0.04 & 0.03 \\
\hline PT Petrosea Tbk/PTRO & 1.63 & 0.76 & 0.00 \\
\hline PT SMR Utama Tbk/SMRU & 1.60 & 4.88 & 0.832 \\
\hline PT Bara laya Internasional TbK/ATPK & 1.12 & 0.00 & 0.00 \\
\hline PT Darma Henwa Tbk/DEWA & 1.09 & 0.13 & 0.01 \\
\hline PT Resource Alam Indonesia Tbk/KKGI & 0.97 & 0.35 & 0.09 \\
\hline PT Borneo Lumbung Energi \& Metal Tbk/BORN & 0.88 & 0.00 & 0.00 \\
\hline PT Golden Eagle Energy Tbk/SMMT & 0.50 & 0.54 & 0.08 \\
\hline PT Garda Tujuh Buana Tbk/GTBO & 0.41 & 0.12 & 0.03 \\
\hline
\end{tabular}

Di lain pihak emiten yang paling aktif ditransaksikan oleh pelaku pasar Tanah Air adalah perusahaan batu bara milik Grup Bakrie, PT Bumi Resources Tbk (BUMI). BUMI membukukan rerata volume transaksi harian sebesar 334,68 juta transaksi dengan total nilai transaksi mencapai Rp 47,07 miliar per harinya. Sepanjang tahun berjalan saham BUMI berhasil mencatatkan imbal hasil $15,53 \%$. Pencapaian tersebut diperoleh di tengah harga batu bara dunia yang terus menunjukkan tren penurunan pada periode yang sama. Untuk diketahui, per 8 Juli 2019, harga batu bara Newcastle tercatat mengalami koreksi $26,31 \%$ ke level US\% 75,2/metrik ton. Lebih lanjut, emiten produsen batu bara lainnya yang juga cukup likuid adalah PT Adaro Energy Tbk/ADRO (61,52 juta transaksi), emiten milik Grup perusahaan. Disamping itu, kebangkrutan juga akan berdampak kepada para investor yang
Sinarmas PT Delta Dunia Makmur Tbk/DOID (28,93 juta transaksi), emiten BUMN PT Bukit Asam Tbk/PTBA $(23,88$ juta transaksi) dan PT Indika Energy Tbk/INDY (21,11 juta transaksi). Kemudian jika ditilik lebih rinci PTBA membukukan nilai transaksi (turnover) lebih tinggi dibandingkan BUMI. Hal ini dikarenakan harga saham PTBA mencapai $\mathrm{Rp}$ 2.980/unit saham, sedangkan bumi hanya Rp 118/unit saham.

Fenomena diatas jika terusmenerus terjadi maka akan mengarah kearah kebangkrutan perusahaan di sub sektor pertambangan, hal ini disebabkan karena kegagalan manajemen dalam mengelola operasional perusahaan untuk menunjang pendapatan. Karena pendapatan adalah salah satu faktor perusahaan dalam mencapai tujuan menginvestasikan uangnya di perusahaan tersebut. Karena bagi para investor perushaaan yang delisted dari 
BEI adalah indicator tanda-tanda bahwa perusahaan tersebut sedang mengalami kebangkrutan. Perusahaan pada sector pertambangan batubara sangatlah rentan dalam kebangkrutan, hal ini sangatlah wajib menjadi pertimbangan para investor sebelum menanamkan uangnya dalam jangka panjang pada Perusahaan sector pertambangan batubara. Hal ini sudah selayaknya perlu dilakukan penelitian yang memprediksi kebangkrutan Perusahaan sector pertambangan batubara.

Dikutip dari CNBC Indonesia menyatakan bahwa data indeks saham perdagangan menunjukkan, bahwa empat emiten tambang baru bara masih melanjutkan pelemahan yang dialami sebelumnya. Indeks mining di Bursa Efek Indonesia di bulan juni 2019 mengalami minus sebesar $0,15 \%$ di level 1.642. adapun perusahaan yang dimaksud adalah yang pertama, Saham PT Harum Energy Tbk (HRUM) turun $0,71 \%$ di level 1.400/saham, melanjutkan koreksi kemarin di level Rp 1.410/saham. Secara tahun berjalan atau year to date saham Harum stagnan. Lalu, Berikutnya saham PT Indo Tambangraya Megah Tbk (ITMG) juga minus 0,59\% di level Rp 16.900/saham, melanjutkan koreksi kemarin di level Rp 17.225/saham. Year to date saham ITMG minus $17 \%$, kemudian, Emiten ketiga yakni PT Adaro Energy Tbk (ADRO) juga terkoreksi $1,17 \%$ di level $\mathrm{Rp}$ 1.270/saham, melanjutkan koreksi saat kemarin di Rp 1.290/saham. Year to date saham Adaro masih naik 5\%. dan Satu emiten lagi yakni PTBA atau PT Bukit Asam Tbk juga minus 0,68\% di level Rp 2.910/saham dan year to date saham perseroan minus hingga $32 \%$.

para analis keuangan. Adapun beberapa alat deteksi kebangkrutan
Data indeks saham perdagangan diatas menunjukkan akan mempengaruhi tidak hanya kepada kinerja perusahaan saja, namun akan berpengaruh terhadap harga saham perusahaan yang berada di wilayah pasar modal. Kinerja perusahaan yang buruk akan menghasilkan saham yang buruk di mata investor. karena saham merupakan bagian dari hasil kinerja perusahaan yang akan menghasilkan nilai bagi setiap perusahaan. Sebaliknya kinerja yang memuaskan menghasilkan nilai perusahaan yang baik dan mencerminkan harga saham yang optimal yang diminati oleh investor. Dalam memperbaiki dan mengevaluasi kinerja perusahaan diperlukannya suatu informasi terkait dalam hal memprediksi harga saham dipasar modal.

terdapat dua pendekatan yang dilakukan oleh analis terkait mengintepretasikan harga saham di masa akan datang. Adapun pendekatan yang dilakukan yaitu pendekatan fundamentalis dan teknikal. Pendekatan fundamentalis memfokuskan pada prediksi harga saham dengan nilai faktor-faktor fundemantalis yang mempengaruhi harga saham, dan menerapkan hubungan antara variabel yang dimiliki sehingga diperoleh taksiran harga. Lalu, Pendekatan teknikal adalah pendekatan berdasarkan pada perilaku harga saham itu sendiri sehingga cenderung akan terulang kembali.

Salah satu contoh pendekatan fundamentalis adalah mengenai alat deteksi kebangkrutan. Pendekatan tersebut telah banyak dilakukan oleh

yang sering digunakan yaitu Model Altman Z-Score (1968), Model Springate $S$-Score (1978), dan Model 
Zmijewski X-Score (1983). Penelitian oleh Hadi dan Anggreni (2008) menemukan bahwa model prediksi Altman merupakan prediktor terbaik diantara ketiga prediktor yang digunakan sebagai analisis yaitu model Altman Z-Score, model Zmijewski $X$ Score, dan Model Springate S-Score.

Pada tahun 1968 telah dilakukan penelitian pertama kali terkait Analisis Z-Score" terhadap perusahaan manufaktur yang telah go public yang dilakukan oleh Edward I Altman. Tahun 1984, private manufacturing company dan go public dijadikan objek dari model kebangkrutan tersebut, dengan tujuan agar tidak hanya perusahaan manufaktur yang telah go public saja yang dapat dijadikan sampel, namun juga perusahaan manufaktur tertutup. Selanjutnya, Altman memodifikasi kembali model Analisis Z-Score" agar dapat digunakan kepada semua jenis perusahaan. hal tersebut terjadi pada tahun 1995. Pada tahun 1978 di Kanada dilakukan penelitian terkait model Springate sebagai pengembangan dari model analisis Altman Z-Score” yang dilakukan oleh
Gordon L.V. Springate dan menghasilkan rumus $S$-Score atau lebih dikenal dengan Model Springate. Pada tahun 1983 dilakukan Penelitian atas pengembangan Altman Z-Score" dan Model Springate yang dilakukan oleh Mark Zmijewski, dan berhasil menghasilkan rumus yang disebut sebagai Zmijewski $X$-Score. Fungsi analisis kebangkrutan dengan modelmodel tersebut memiliki tujuan yang sama, yaitu sama-sama memprediksi apakah perusahaan dalam keadaan sehat, normal, atau kemungkinan bangkrut. Hal ini berdasarkan kondisi perusahaan yang bersumber dari informasi laporan keuangan yang diberikan oleh perusahan yang berada di masing -masing negara.

Penelitian ini menggunakan dua metode prediksi kebangkrutan untuk mengetahui pengaruhnya terhadap harga saham, yaitu Altman Z-Score" dan Springate $S$-Score karena berdasarkan penelitian-penelitian sebelumnya tingkat keakuratan kedua metode ini dinilai hampir memiliki persamaan dalam memprediksikan kondisi perusahaan. 
B. KAJIAN LITERATUR

\section{Hipotesis Penelitian}

a. Pengaruh Altman Z-Score" sebagai alat prediksi potensi kebangkrutan terhadap harga saham

Menurut Ross (1977), sesuai dengan Signaling theory, Informasi dari keputusan manajerial dan struktur keuangan suatu perusahaan akan menjadi sebuah sinyal atau tanda terhadap pasar yang akan merubah keseimbangan pasar. Hubungan antara publikasi informasi baik laporan keuangan, kondisi keuangan ataupun sosial politik terhadap fluktuasi volume perdagangan saham dapat dilihat dalam efisiensi pasar. Suatu prediksi tentang kebangkrutan pada suatu perusahaan bisa menjadi sebuah sinyal bagi para investor sebelum melakukan investasi dalam bentuk saham dan sekuritas perusahaan tersebut. Informasi kebangkrutan sangat bermanfaat bagi investor untuk mengurangi risiko saham.

Menurut Suharto (2015) menyatakan bahwa hasil metode Altman Z-Score" menunjukkan bahwa beberapa perusahaan yang listing dalam Daftar Efek Syariah periode 2011 sampai 2013 diprediksi mengalami kebangkrutan dan presentasenya meningkat setiap tahunnya yaitu $17,7 \%$ di tahun 2011, kemudian $25,8 \%$ di tahun 2012 dan sebesar $29 \%$ pada tahun 2013. Potensi kebangkrutan perusahaan tersebut dapat semakin bertambah pada masa yang akan datang apabila pihak manajemen perusahaan tidak melakukan perbaikan terhadap kondisi keuangan perusahaan. Hal ini membuktikan bahwa metode ini bisa digunakan sebagai pendeteksi dini terhadap potensi kebangkrutan perusahaan dari sisi keuangan perusahaan, karena kebangkrutan suatu perusahaan tidak hanya dilihat dari sisi keuangan atau internal saja melainkan banyak factor lain yang menjadi penyebab kebangkrutan perusahaan seperti faktor eksternal perusahaan.

Lalu hasil menurut penelitian yang dilakukan oleh kurniawan (2018) meyatakan bahwa Altman Z-Score" berpengaruh positif terhadap Harga Saham. Hasil ini juga sesuai dengan teori bahwa para investor juga mengakui dan menyesuaikan posisi baru dari perusahaan yang mengalami kebangkrutan yang selanjutnya rasio keuangan tersebut memberikan informasi ke dalam harga saham. Lalu menurut hasil penelitian Manao dan Nur (2001) menyatakan bahwa kinerja keuangan yang melemah terhadap variasi harga saham dapat disebabkan penggunaan kurs harga saham akhir tahun. Hal tersebut juga dapat menurunkan tingkat empiris dalam penelitian karena terjadi berbagai faktor yang mempengaruhi seperti stock split, merger, bonus, dan transaksi lain yang menpengaruhi lemahnya harga saham.

Penjelasan diatas dapat disimpulkan bahwa dengan tingginya harga saham yang dihasilkan oleh perusahaan maka hal tersebut akan membuat investor akan tertarik untuk menanamkan uangnya, karena mereka lebih mempercayai informasi ketika perusahaan 
dianggap tidak mengalami kondisi kebangkrutan.

\section{$\mathrm{H}_{1}$ : Altman Z-Score" sebagai alat prediksi potensi kebangkrutan berpengaruh terhadap Harga Saham.}

b. Pengaruh Springate S-Score sebagai alat prediksi potensi kebangkrutan terhadap Harga Saham

Analisis terhadap kinerja keuangan mutlak diperlukan agar investor dan calon investor dapat mengetahui kondisi perusahaan yang akan menjadi sarana investasinya, atau untuk menentukan perusahaan yang dapat memberikan keuntungan atas penanaman modal mereka. Perusahaan yang kinerja keuangannya baik akan mampu memberikan keuntungan bagi investornya. mengkonfirmasi adanya hubungan negatif antara harga saham dengan prediksi kebangkrutan, dimana perusahaan yang memiliki risiko kebangkrutan yang tinggi cenderung akan direspon negatif oleh investor dan akibatnya adalah harga saham menjadi turun

Perhitungan secara keseluruhan dapat disimpulkan bahwa, jika melihat dari sisi prediksi kebangkrutan perusahaan pertambangan batubara yang masuk dalam kategori bangkrut, maka model Altman Z-Score dan model Springate yang memberikan peenilaian prediksi kebangkrutan yang tinngi. Sedangkan pada model Zmijewski prediksi kebangkrutan yang dihasilkan juga bernilai cukup tinggi meskipun tidak setinggi prediksi yang dibeerikan model Altman Z-Score dan model Springate. Perbandingan ketiga model Altman Z-Score, model Springate dan model Zmijewski memberikan gambaran perusahaan pertambangan batubara termasuk dalam kategori perusahaan yang mengalami kebangkrutan. Namun jika hal ini Springate S-Score sebagai model kebangkrutan yang digunakan untuk mengetahui kondisi perusahaan tentunya akan memberikan pengaruh terhadap harga saham yang sangat disensitif akan informasi yang berasal dari kinerja perusahaan. Semakin tinggi nilai S-Score yang artinya nilai tersebut melewati batas yang diprediksikan perusahaan mengalami kondisi tidak sehat maka semakin tinggi juga harga saham tersebut karena harga saham menurut arbitrage pricing theory informasi kesehatan perusahaan akan mempengaruhi harga saham.

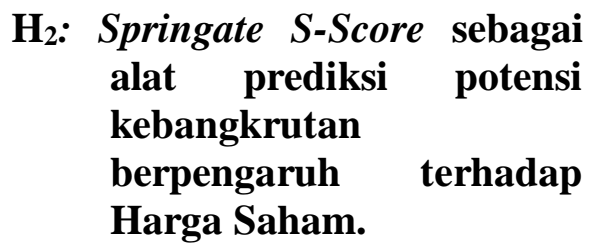




\section{METODE PENELITIAN}

\section{Populasi dan Sampel}

Populasi dalam penelitian ini adalah 6 perusahaan Batubara yang terdaftar pada Bursa Efek Indonesia (BEI) selama periode 2016-2018. Kriteria yang digunakan untuk memilih sampel yaitu Perusahaan Batubara yang terdaftar di BEI pada tahun 2016-2018, Perusahaan mempublikasikan laporan keuangan dengan lengkap dan Laporan keuangan tahunan yang diterbitkan menggunakan nilai mata uang rupiah (Rp).

\section{Variabel dependen}

\section{a. Harga Saham (Y)}

Dalam penelitian ini terdapat satu variabel dependen yaitu Harga Saham (Y). Variabel ini merupakan dari suatu saham pada pasar yang sedang berlangsung atau jika pasar sudah ditutup, maka harga pasar adalah harga penutupnya (closing price). Skala pengukuran data dari variabel ini diukur dengan skala nominal. Skala nominal adalah skala yang pengukurannya menyatakan kategori, atau kelompok dari suatu subyek (Ghozali, 2011).

\section{Variabel Independen}

a. Altman Z-Score"' $\left(\mathrm{X}_{1}\right)$ Menurut Prihadi (2013) Altman Z-Score" adalah hasil score yang telah dimodifikasi oleh Altman pada tahun 1995 yang dapat diterapkan pada semua jenis perusahaan. Model terakhir yang telah dimodifikasi oleh Altman pada tahun 1995 sehingga dapat diterapkan kepada semua jenis perusahaan baik di negara maju maupun negara berkembang. Berikut model
Altman Z-Score yang telah dimodifikasi:

$Z "=6,56 X_{1}+3,26 X_{2}+6,72 X_{3}+1,05 X_{4}$

Keterangan:

Z" = Bangkruptcy index

$\mathrm{X}_{1} \quad=$ Working capital/

Total asset

$\mathrm{X}_{2} \quad=$ Retained earning/

Total asset

$\mathrm{X}_{3} \quad=$ Earning Before

Interest and Taxes/ Total asset

$\mathrm{X}_{4} \quad=$ Book value of equity/

Book value of total debt

Klasifikasi perusahaan yang sehat dan bangkrut berdasarkan pada nilai Z-Score model Altman Modifikasi (1995), yaitu:

- Jika nilai Z" $<1,1$ = maka termasuk perusahaan yang bangkrut.

- Jika nilai $1,1<\mathrm{Z}$ " $<2,6=$ maka termasuk grey area (tidak dapat ditentukan apakah perusahaan sehat ataupun mengalami kebangkrutan).

- Jika nilai Z" > 2,6 = maka termasuk perusahaan yang tidak bangkrut.

\section{b. Springate $\mathbf{S}$-Score $\left(\mathbf{X}_{2}\right)$} Metode Springate merupakan metode yang menganalisis dengan mengembangkan metode yang digunakan oleh Altman Z-Score". Variabel yang digunakan dalam penelitian ini dibagi menjadi empat rasio keuangan berdasarkan A, B, C, dan D yang dijelaskan sebagai berikut: Persamaan metode yang diteliti oleh Springate menghasilkan rumus sebagai berikut (Putra dan Ferlina, 2014): 


$$
\mathrm{S}=1,03 \mathrm{~A}+3,07 \mathrm{~B}+0,66 \mathrm{C}+0,4 \mathrm{D}
$$

Keterangan:

$\mathrm{S}=$ Bangkruptcy index

$\mathrm{D}=$ Sales/Total assets
$\mathrm{A}=$ Working capital/Total assets

$\mathrm{B}=$ Net Profit before Interest and

Taxes/Total assets

$\mathrm{C}=$ Net Profit before

Taxes/Current liabilities

\section{HASIL DAN PEMBAHASAN}

1. Hasil Uji Statistik Deskriptif

Tabel 2

Hasil Analisis Statistik Deskriptif

Descriptive Statistics

\begin{tabular}{|l|r|r|r|r|r|}
\hline & $\mathrm{N}$ & Minimum & Maximum & Mean & Std. Deviation \\
\hline Z_Score & 36 & .00 & 32.00 & 6.2500 & 6.29909 \\
S_Score & 36 & -1.00 & 55.00 & 2.1389 & 9.10621 \\
Harga_Saham & 36 & 1.04 & 720.00 & $1.1024 \mathrm{E} 2$ & 198.62762 \\
Valid N (listwise) & 36 & & & & \\
\hline
\end{tabular}

a. Berdasarkan tabel diatas dapat dideskripsikan bahwa Variabel Altman Z-Score" $\left(\mathrm{X}_{1}\right)$ memiliki nilai minimum 0,00 dan nilai maksimum 32,00 , nilai mean sebesar 6,2500 dan standar deviasi sebesar 6,299, hal ini menunjukkan bahwa $62,99 \%$ ratarata Z Score". Standar deviasi sebesar $62,99 \%$ menunjukkan total Z Score" dari perusahaan-perusahaan sampel yang diteliti memiliki perbedaan yang relatif tinggi.

b. Variabel Springate S-Score $\left(\mathrm{X}_{2}\right)$ memiliki nilai minimum $-1,00$ dan nilai maksimum 55,00, nilai mean sebesar 2,1389 dan standar deviasi sebesar 9,106. Hal ini menunjukkan bahwa $91,06 \%$ rata rata $S$ Score. Standar deviasi sebesar $91,06 \%$ menunjukkan S Score dari perusahaan - perusahaan sampel yang diteliti memiliki perbedaan yang relatif tinggi.

c. Variabel Harga Saham sebagai variabel dependen (y) memiliki nilai terendah 1,04 dan nilai tertinggi 720,00 nilai rata-rata (mean) sebesar 1,102 dengan standar deviasi sebesar 198,6. Nilai mean sebesar 198,6 $(19,86 \%)$ menunjukkan bahwa ratarata Harga Saham sampel yang diteliti adalah sebesar 19,86\% dari total Harga Saham. Standar deviasi sebesar 19,86\% menunjukkan bahwa Harga Saham dari perusahaanperusahaan sampel yang diteliti memiliki perbedaan yang relative tinggi.

\section{Hasil Uji Normalitas}

Tabel 2

Hasil Uji Normalitas

One-Sample Kolmogorov-Smirnov Test

\begin{tabular}{|l|r|}
\hline & Unstandardized Predicted Value \\
\hline N & 36 \\
Normal Parameters & a \\
\hline
\end{tabular}




\begin{tabular}{|ll|r|} 
& Std. Deviation & $1.23336670 \mathrm{E} 2$ \\
& Absolute & .171 \\
& & .141 \\
& Positive & -.171 \\
& Negative & 1.027 \\
Kolmogorov-Smirnov Z & & .242 \\
Asymp. Sig. (2-tailed) & & \\
\hline a. Test distribution is Normal. &
\end{tabular}

Dari data output SPSS di atas dapat dilihat bahwa nilai Asymp. Sig. (2-tailed) sebesar 0,242 lebih besar dari 0,05, sehingga data dapat dikatakan berdistribusi normal.

\section{Hasil Uji Heteroskedastisitas}

Tabel 3

Hasil Uji Heteroskedastisitas

Coefficients $^{\mathrm{a}}$

\begin{tabular}{|c|c|c|c|c|c|c|}
\hline \multirow{2}{*}{\multicolumn{2}{|c|}{ Model }} & \multicolumn{2}{|c|}{ Unstandardized Coefficients } & \multirow{2}{*}{$\begin{array}{c}\begin{array}{c}\text { Standardized } \\
\text { Coefficients }\end{array} \\
\text { Beta }\end{array}$} & \multirow[b]{2}{*}{$\mathrm{T}$} & \multirow[b]{2}{*}{ Sig. } \\
\hline & & $\mathrm{B}$ & Std. Error & & & \\
\hline \multirow[t]{3}{*}{1} & (Constant) & 79.104 & 25.536 & & 3.098 & .004 \\
\hline & Z_Score & 5.652 & 3.087 & .322 & 1.831 & .076 \\
\hline & S_Score & -2.969 & 2.135 & -.245 & -1.390 & .174 \\
\hline
\end{tabular}

a. Dependent Variable: ABS_RES

Berdasarkan hasil uji heteroskedastisitas melalui uji glejser dapat diketahui bahwa nilai signifikansi setiap variable independen berada di atas atau lebih tinggi dibandingkan dengan nilai signifikansi yang digunakan yaitu 0,05 . Oleh karena itu, dapat disimpulkan bahwa tidak terjadi heteroskedastisitas pada variable independen yang digunakan pada penelitian ini.

\section{Hasil Uji Multikolineritas}

Tabel 4

Hasil Uji Multikolineritas

Coefficients $^{a}$

\begin{tabular}{|c|c|c|c|c|c|c|c|}
\hline \multirow[b]{2}{*}{ Model } & \multicolumn{2}{|c|}{$\begin{array}{l}\text { Unstandardized } \\
\text { Coefficients }\end{array}$} & \multirow{2}{*}{$\begin{array}{c}\begin{array}{c}\text { Standardized } \\
\text { Coefficients }\end{array} \\
\text { Beta }\end{array}$} & \multirow[b]{2}{*}{$\mathrm{T}$} & \multirow[b]{2}{*}{ Sig. } & \multicolumn{2}{|c|}{ Collinearity Statistics } \\
\hline & B & Std. Error & & & & Tolerance & VIF \\
\hline $1 \quad$ (Constant) & -6.900 & 38.063 & & -.181 & .857 & & \\
\hline Z_Score & 20.871 & 4.602 & .662 & 4.536 & .000 & .874 & 1.144 \\
\hline S_Score & -6.220 & 3.183 & -.285 & -1.954 & .059 & .874 & 1.144 \\
\hline
\end{tabular}

a. Dependent Variable: Harga_Saham

Berdasarkan uji Multikolinieritas yang dilakukan terhadap variabel Z Score, S Score dan Harga Saham diperoleh data seperti yang ada dalam tampilan tabel di atas. Hasil perhitungan dari
SPSS menunjukkan tidak ada variabel independen yang memiliki nilai tolerance kurang dari 0,10 yang berarti tidak ada korelasi antarvariabel independen yang nilainya lebih dari 95\%. Hasil 
perhitungan nilai Variance Inflation Factor (VIF) juga menunjukkan tidak ada variabel independen yang memiliki nilai VIF lebih dari 10. Jadi, dapat disimpulkan bahwa tidak ada Multikolinieritas antar variabel independen dalam model regresi yang digunakan dalam penelitian ini.

\section{Hasil Uji Autokorelasi}

Tabel 5

Hasil Uji Autokorelasi Model Summary ${ }^{b}$

\begin{tabular}{|l|r|r|r|r|r|}
\hline Model & \multicolumn{1}{|c|}{$\mathrm{R}$} & R Square & \multicolumn{1}{|c|}{$\begin{array}{c}\text { Adjusted R } \\
\text { Square }\end{array}$} & $\begin{array}{c}\text { Std. Error of the } \\
\text { Estimate }\end{array}$ & Durbin-Watson \\
\hline 1 & $.621^{\mathrm{a}}$ & .386 & .348 & 160.34384 & $\mathbf{1 . 8 6 9}$ \\
\hline
\end{tabular}

a. Predictors: (Constant), S_Score, Z_Score

b. Dependent Variable: Harga_Saham

\begin{tabular}{|c|c|c|}
\hline Hipotesis Nol & Keputusan & Jika \\
\hline $\begin{array}{c}\text { Tidak ada autokorelasi, positif atau } \\
\text { negative }\end{array}$ & Tidak Ditolak & $\mathrm{du}<\mathrm{d}<4$-du \\
& & $1.5872<\mathbf{1 . 8 6 9}<2.131$ \\
\hline
\end{tabular}

Berdasarkan tabel di atas nilai Durbin Watson sebesar 1.869, pembanding menggunakan nilai signifikansi 5\%, jumlah sampel 36 (n), dan jumlah variabel independen $2(\mathrm{k}=2)$, maka di tabel Durbin Watson akan didapat nilai du sebesar 1,5872. Karena nilai DW 1,869 lebih besar dari batas atas (du) 1,869 dan kurang dari 4 1.869 (2.131), maka dapat disimpulkan bahwa tidak terdapat autokorelasi.

\section{Hasil Uji Linieritas}

Tabel 6

Hasil Uji Linieritas

\begin{tabular}{|l|l|l|}
\hline \multicolumn{1}{|c|}{ Model } & \multicolumn{1}{c|}{ Sig } & \multicolumn{1}{c|}{ Keterangan } \\
\hline Harga Saham *Z Score" & $\mathbf{0 , 0 8 0}$ & Liniear \\
\hline Harga Saham *S Score & $\mathbf{0 , 4 6 9}$ & Liniear \\
\hline
\end{tabular}

Berdasarkan uji linearitas melalui program SPSS dapat diketahui bahwa variabel Z Score, $S$ Score dan Harga Saham menghasilkan nilai signifikansi di diatas 0,05, maka dapat disimpulkan data berbentuk fungsi linear atau ada hubungan linier. 


\section{Uji Hipotesis}

a. Uji Adjusted $\mathbf{R}^{2}$ (Koefisien determinasi)

Tabel 7

Hasil Uji Adjusted $\mathbf{R}^{2}$

\begin{tabular}{|c|c|c|c|}
\hline Model & R & R Square & $\begin{array}{c}\text { Adjusted R } \\
\text { Square }\end{array}$ \\
\hline 1 & $.621^{\mathrm{a}}$ & .386 & $\mathbf{. 3 4 8}$ \\
\hline
\end{tabular}

b. Dependent Variable: Harga Saham

Sumber: Hasil Olahan Eviews 9.0, 2019

Hasil Adjusted R-Squared pada model ini adalah 0,348 artinya bahwa variasi perubahan naik turunnya Harga Saham dapat dijelaskan oleh Z-Score" dan S-Score sebesar $34.8 \%$, sedangkan sisanya $65.2 \%$ disebabkan oleh variabel atau hal lain diluar dari variabel yg diteliti.

\section{b. Uji t Parsial}

Tabel 8

Hasil Uji t Parsial

\begin{tabular}{|l|c|c|c|}
\hline \multirow{2}{*}{ Model } & Unstandardized Coefficients & \\
\cline { 2 - 3 } & B & Nilai T & Nilai Sig. \\
\hline 1 (Constant) & -6.900 & -0.181 & .857 \\
Z Score & 20.871 & 4.536 & .000 \\
S Score & -6.220 & -1.954 & .059 \\
\hline
\end{tabular}

a. Dependent Variable: Harga Saham

Sumber: Hasil Olahan Eviews 9.0, 2019

Berdasarkan hasil uji t pada analisis resgresi panel menunjukan, maka dapat disimpulkan hasil hipotesis sebagai berikut:

1) Pengujian hipotesis pertama $\left(\mathrm{H}_{1}\right)$

Nilai t-hitung Altman ZScore" sebesar 4,536, sementara $t_{\text {tabel }}$ dengan tingkat $\alpha=5 \%$, df $(\mathrm{n}-\mathrm{k})=36-$ 2 didapat nilai $t_{\text {tabel }}$ sebesar 1.690. Dengan demikian t. hitung Altman Z-Score" $(4,536)>t_{\text {tabel }}(1.690)$ dan nilai Sig. $0,000<0,05$ maka dapat disimpulkan bahwa variabel Altman Z-Score" dalam penelitian ini memiliki pengaruh terhadap Harga 
Saham. Altman Z-Score" mempunyai koefisien regresi kearah positif sebesar 20,871 $(20,87 \%)$ dengan Konstanta kearah negatif sebesar 6.900. Hal ini berarti semakin tinggi nilai Altman Z-Score" sebagai alat prediksi potensi kebangkrutan suatu perusahaan, maka akan berdampak pada penurunan Harga Saham. Hal ini terjadi dikarenakan kinerja keuangan yang melemah terhadap variasi harga saham dapat disebabkan penggunaan kurs harga saham akhir tahun. Hal tersebut juga dapat menurunkan tingkat empiris dalam penelitian karena terjadi berbagai faktor yang mempengaruhi seperti stock split, merger, bonus, dan transaksi lain yang menpengaruhi lemahnya harga saham (Manao dan nur; 2001).

\section{E. KESIMPULAN}

Hasil Penelitian dari pengujian ini menghasilkan bahwa Variabel Altman Z-Score" secara parsial berpengaruh positif terhadap Harga Saham, namun berbeda dengan hasil Springate S-Score yang secara parsial tidak berpengaruh terhadap Harga Saham.

\section{DAFTAR PUSTAKA}

Abbas, Dirvi Surya, Ali Kusuma Wardhana, and Ahmad Saefudin. "Faktor-Faktor Yang Mempengaruhi Manajemen Laba (Pada Perusahaan Sub Sektor
2) Pengujian hipotesis kedua $\left(\mathrm{H}_{2}\right)$

Nilai t- hitung Springate S-Score sebesar $\quad-1.954$ sementara $t_{\text {tabel }}$ dengan tingkat $\alpha=5 \%$, df (n-k) = 362 didapat nilai $t_{\text {tabel }}$ sebesar 1.690. Dengan demikian t. hitung Springate S-Score (1.954) $>t_{\text {tabel }}(1.690)$ dan nilai Prob. $0.059>0,05$ maka dapat disimpulkan bahwa variabel Springate S-Score dalam penelitian ini tidak memiliki pengaruh terhadap Harga Saham. Springate SScore mempunyai koefisien regresi kearah negatif sebesar $-6,220 \quad(62,20 \%)$ dengan Konstanta kearah negatif sebesar -6.900. Hal ini berarti semakin rendah nilai Springate $S$-Score sebagai alat prediksi potensi kebangkrutan suatu perusahaan, maka akan berdampak pada penurunan Harga Saham.

Properti dan Real Estate yang terdaftar di BEI pada tahun 20162018)." Balance Vocation Accounting Journal 2.2 (2018): 4758.

Abbas, Dirvi Surya. "Pengaruh Current Ratio, Account Receivable Turnover, Inventory Turnover, Total Asset Turnover dan Debt To Equity terhadap Return on Asset (Pada Perusahaan manufaktur sub sektor otomotif dan komponen yang Terdaftar di Bursa Efek Indonesia Pada Tahun 2011-2014)." COMPETITIVE 2.1 (2017): 55-72. Andriawan, Nur Fadli \& Dantje Salean. (2016). Analisis Metode Altman ZScore sebagai Alat Prediksi 
Kebangkrutan dan Pengaruhnya terhadap Harga Saham pada Perusahaan Farmasi yang terdaftar di Bursa Efek Indonesia. Jurnal Ekonomi Akuntansi Vol. 1 No. 1, hal 67-82. Surabaya. Universitas 17 Agustus 1945.

Effendi, Azhar Affandi, dan Iwan Sidharta. (2016) Analisa Pengaruh Rasio Keuangan Model Springate terhadap Harga Saham pada Perusahaan Publik Sektor Telekomunikasi. Jurnal Ekonomi, Bisnis dan Entrepreneurship Vol. 10 No. 1, April 2016, hal 116. Bandung: Universitas Pasundan.

Hadi, Syamsul \& Atika Anggreini. (2008). Pemilihan Prediktor Delisting Terbaik (Perbandingan Antara The Zmijewski Model, The Altman Model, dan The Springate Model). Fakultas Ekonomi Universitas Islam Indonesia. (Diambil dari: www.jurnal.uii.ac.id/index.php/JA AI/article/viewFile/2263/2065 pada tanggal 20 Juni 2017).

Ida \& Santoso. (2011). Analisis Kebangkrutan Dengan Menggunakan Metode Springate (diakses online pada tanggal 25 Juni 2017 melalui web www.tsm.ac.id/MB/MB.3.1.Maret.2 011/Analisis\%20Kebangkrutan\%20 den

gan\%20menggunakan\%20Metode $\% 20$ Springate.pdf).

Kamal, St. Ibrah Mustafa. (2012). Analisis Prediksi Kebangkrutan pada Perusahaan Perbankan Go Public di Bursa Efek Indonesia. Skripsi. Makassar: Universitas Hassanuddin.

Manao, Hekinus \& Nur Deswin. (2001). Analisis asio Keuangan dengan Return Saham : Pertimbangan Ukuran Perusahaan Serta
Pengaruh Krisis Ekonomi di Indonesia, Simposium Nasional Akuntansi IV. IAI. Oktober.

Marcelina, Tri Ayu. (2014). Prediksi Kebangkrutan Menggunakan Metode Z- Score dan Pengaruhnya terhadap Harga Saham pada Perusahaan Transportasi yang terdaftar di BEI tahun 2008-2012. Jurnal e-Proceeding of Management. Vol 1 No. 3, Hal 291. Bandung: Universitas Telkom

Meita, Elvinna Wiwit Firma. (2015). Analisis Penggunaan Metode Altman, Springate, Dan Zmijewski Dalam Memprediksi Kebangkrutan Perusahaan Pertambangan Batubara Periode 2012-2014. Fakultas Ekonomi Universitas Negeri Surabaya. (Diakses online dari web. www.ejournal.ikippgrimadiun.ac.id/index. php/assets/article/.../992 pada tanggal 20 Juni 2017).

Hakim, Mohamad Zulman, And Dirvi Surya Abbas. "Pengaruh Ukuran Perusahaan, Struktur Modal, Likuiditas, Investment Opportunity Set (Ios), Dan Profitabilitas Terhadap Kualitas Laba (Perusahaan Makanan Dan Minuman Yang Terdaftar Di Bursa Efek Indonesia Tahun 2013-2017)." Competitive 3.2 (2019): 26-51.

Nurhayati, Dede. (2015). Pengaruh Prediksi Kebangkrutan Dengan Menggunakan Metode Altman ZScore dan Springate terhadap Harga Saham di Perusahaan Perbankan yang Terdaftar di Bursa Efek Indonesia. Skripsi. Bandung: Universitas Pasundan.

Putra \& Ferlina. (2014). Analisis Prediksi Tingkat Kebangkrutan Perusahaan Deengan Metode Altman Z-Score Dan Springate (Studi Kasus Pada Perusahaan Sub Sektor Pertambangan 
Minyak Dan Gas Bumi Yang Tercatat Di Bursa Efek Indonesia Pada Tahun 2009-2012. Jurnal Studi Manajemen Dan Bisnis Vol.1 No. 22 Tahun 2014

Prihadi, Toto. (2013). Analisis Laporan Keuangan. Teori dan aplikasi. Jakarta: PPM

Ross, Stephen A. (1997). The determination of financial structure: the incentive-signalling approach. The Bell Journal of Economics, Vol. 8, No. 1 (Spring, 1977), pp. 23-40

Suharto. (2015). Analisis Prediksi Financial Distress dan Kebangkrutan Pada PerusahaanPerusahaan yang Listing Dalam Daftar Efek Syariah dengan Model
Altman Z-Score. Skripsi. Semarang: UIN Walisongo

https://katadata.co.id/berita/2019/07/16/ha rga-acuan-anjlok-eksporbatu-bara-semester-i-turun498

https://duniatambang.co.id/ForumKategori /read/112/Terendah-Sejak-2-

Tahun-Terakhir-Harga-

Batubara-Acuan-MakinLesuh 2019-09-10

https://www.cnbcindonesia.com/market/20 190611093352-17-

77506/kemarin-anjlok-sahamemiten-batu-bara-amblas-lagi

https://www.cnbcindonesia.com/market/20 190709150531-17-

83672/mau-jajan-saham-batubara-simak-mana-yang-likuid 